\title{
Triple Therapy with Single Daily Dose of Cyclosporine in Japanese Patients with Idiopathic Membranous Nephropathy
}

\author{
Hiroshi Matsumoto, Yume Nagaoka, Tomonari Okada, Toshikazu Wada, Asako Gondo, \\ Shinga Esaki, Ami Hayashi, Yoshitaka Miyaoka and Toshiyuki Nakao
}

\begin{abstract}
Objective The optimal therapeutic approach to patients with idiopathic membranous nephropathy (IMN) remains controversial. In this study, we assessed the efficacy of single daily dose cyclosporine (CsA) combined with low-dose prednisolone (PSL) and an angiotensin II receptor blocker (ARB) in patients with IMN.

Methods We studied 13 nephrotic patients ( 8 men, 5 women) with IMN diagnosed on biopsy. An initial single daily dose of $2 \mathrm{mg} / \mathrm{kg}$, but not exceeding $150 \mathrm{mg}$, CsA was given for 12 months, tapered by a $25 \mathrm{mg}$ reduction every 2 months. An initial twice-daily dose of $0.5 \mathrm{mg} / \mathrm{kg}$ PSL was given for 2 months and was also tapered. An ARB was given to all patients and the same dosage was used throughout the study. Patients were followed up for 6 to 66 months.

Results Nine patients achieved complete remission at $6.7 \pm 2.9$ months, and incomplete remission was obtained in the remaining patients. After a follow-up period of $32.7 \pm 20.0$ months, their serum creatinine and estimated glomerular filtration rate values were similar to baseline levels. The 9 patients who completed the treatment course have not relapsed. Moreover, there were no adverse effects requiring discontinuation of this triple therapy.

Conclusion A single daily dose of CsA combined with a low dose of PSL and an ARB in new-onset nephrotic patients with IMN induced a high remission rate of nephrotic syndrome, with a low incidence of relapse and a low risk of adverse effects. The triple therapy and prospective follow-up shows potential as a treatment approach for patients with IMN.
\end{abstract}

Key words: Cyclosporine, Angiotensin II receptor blocker, Prednisolone, Nephrotic syndrome, Complete remission

(Intern Med 50: 1905-1910, 2011)

(DOI: 10.2169/internalmedicine.50.5606)

\section{Introduction}

Idiopathic membranous nephropathy (IMN) with persistent heavy proteinuria has a poor prognosis (1). However, to date, the optimal therapeutic approach for this condition has not been established. Hogan et al (2) stated in their review that recent randomized control trials (RCTs) have not provided sufficient evidence of the benefits of corticosteroids alone (2). On the other hand, several RCTs have documented the benefits of cytotoxic agents, cyclophosphamide or chlorambucil, individually combined with corticosteroids $(3,4)$. However, these agents have potential lifethreatening adverse effects (5). In a recent RCT, a twicedaily dose of cyclosporine (CsA) combined with corticosteroids significantly reduced proteinuria and slowed the rate of disease progression (6). In other studies, a single daily dose of CsA was associated with fewer adverse effects $(7,8)$ than a twice-daily dose, and was shown to be effective in children with focal segmental glomerulosclerosis with steroidresistant nephrotic syndrome (7).

Angiotensin receptor blockers (ARBs) or angiotensin- 
converting enzyme inhibitors have antiproteinuric effects on chronic proteinuric diseases even in normotensive cases, although their efficacy has not yet been completely proven for IMN (9). Furthermore, concomitant use of these agents in experimental CsA nephropathy prevented renal fibrosis $(10,11)$.

In this study, we evaluated the efficacy of a single daily dose of CsA combined with a low dose of prednisolone (PSL) and an ARB in Japanese nephrotic patients with IMN.

\section{Methods}

\section{Patients}

We prospectively studied 18 IMN patients with new-onset nephrotic syndrome who were admitted to our department between 2005 and 2009. One patient with an elevated serum creatinine level of $2.2 \mathrm{mg} / \mathrm{dL}, 2$ with advanced malignancy and 2 who declined this triple therapy were excluded from the study. The remaining 13 patients ( 8 men, 5 women, age range 35 to 83 years) were included in the study. IMN was diagnosed by light microscopy and immunofluorescence studies, together with electron microscopy. Secondary causes of membranous nephropathy, including malignancy, hepatitis $\mathrm{B}$ or $\mathrm{C}$ virus infection, systemic lupus erythematosus, putative drugs, or toxins, were excluded. At study entry, none of the patients were being treated with corticosteroids, immunosuppressive agents, or ARBs. Currently in Japan, the protocol to give CsA with prednisolone from the initial day or to give CsA once daily is based on a close adaptation of the national health insurance. However, all patients were fully informed of the benefits and risks of this treatment and provided written informed consent. Moreover, the study was carried out in accordance with the revised Declaration of Helsinki guidelines of 2000.

\section{Definitions}

Nephrotic syndrome was defined as the presence of pitting edema, profound proteinuria $>3.5 \mathrm{~g} / \mathrm{d}$, and a serum albumin level $<3.0 \mathrm{~g} / \mathrm{dL}$. Complete remission was defined as protein excretion $<0.3 \mathrm{~g} / \mathrm{d}$, whereas incomplete remission was defined as resolution of nephrotic syndrome but continuing proteinuria, and was divided into two grades showing $<1.0 \mathrm{~g} / \mathrm{d}$ of urinary protein excretion (incomplete remission I) and 1.0 to $3.5 \mathrm{~g} / \mathrm{d}$ (incomplete remission II), respectively. Relapse was defined as recurrence of nephrotic range proteinuria after remission.

\section{Histopathologic parameters}

The degree of glomerular sclerosis, tubulointerstitial changes (interstitial fibrosis, tubular atrophy and mononuclear cell infiltration), and vascular lesions (hyalinosis of arterioles and intimal thickening of small arteries) were evaluated by a pathologist. The severity of glomerular sclerosis was expressed as a percentage of totally sclerosed glomeruli, whereas that of tubulointerstitial changes or vascular lesions was assessed using the semi-quantitative scoring (0-4): $0=$ absent, $1=$ mild, $2=$ moderate, $3=$ severe.

\section{Treatment protocol}

After admission, all patients were administered $0.8 \mathrm{~g} / \mathrm{kg} / \mathrm{d}$ of dietary protein and $6 \mathrm{~g} / \mathrm{d}$ of salt. Thirteen patients were treated with a single daily dose of CsA (Neoral, Novartis Pharma Co., Tokyo, Japan) plus a twice-daily dose of PSL and an ARB. A further $2 \mathrm{mg} / \mathrm{kg} / \mathrm{d}$ (but not exceeding 150 $\mathrm{mg} / \mathrm{d})$ CsA was given before breakfast for 12 months, tapered by $25 \mathrm{mg}$ every 2 months, and then stopped. During the initial administration of CsA, the 2-hour total blood (C2) levels after dosing were monitored every 2 months with specific monoclonal radioimmunoassay methods. The lower limits of C2 levels were not adjusted, but the upper limits were targeted to maintain levels below 1,500 ng/mL (12). When serum creatinine levels increased to more than $30 \%$ of baseline values, the CsA dose was reduced by $25 \mathrm{mg}$ until returning to less than $30 \%$ of baseline values. An initial PSL dose of $0.5 \mathrm{mg} / \mathrm{kg} / \mathrm{d}$ (up to $40 \mathrm{mg} / \mathrm{d}$ ) was given for 2 months, and the daily dose was tapered by $5 \mathrm{mg}$ every 2 months until the dosage was reduced to $10 \mathrm{mg} / \mathrm{d}$. Thereafter, $10 \mathrm{mg} / \mathrm{d}$ or $5 \mathrm{mg} / \mathrm{d}$ of PSL was maintained for 2 months, and then stopped. An ARB [valsartan $(\mathrm{n}=8)$ 40-160 mg/d, losartan $(\mathrm{n}=2) 50 \mathrm{mg} / \mathrm{d}$, candesartan $(\mathrm{n}=2) 8-12 \mathrm{mg} / \mathrm{d}$, and olmesartan $(\mathrm{n}=1) 40 \mathrm{mg} / \mathrm{d}$ ] was administered to all patients, even to those with normal blood pressure, and the same dosages were used during the study.

Discharge was considered by attending physicians when edema disappeared and urinary protein excretion decreased to $<3.5 \mathrm{~g} / \mathrm{d}$, or to less than half of the value on admission. After discharge, all patients were followed up monthly as outpatients. On every visit, they were asked about their salt and protein restriction diet and instructed to take $0.8 \mathrm{~g} / \mathrm{kg} / \mathrm{d}$ of dietary protein and $6 \mathrm{~g} / \mathrm{d}$ of $\mathrm{NaCl}$ by a dietician.

\section{Assessment of clinical efficacy}

We evaluated the induction rate of remission (complete remission or partial remission), the relapse rate after a treatment course, and the rate of sustained remission at final observation. Other evaluations included renal function (serum creatinine and estimated glomerular filtration rate (eGFR) (13), blood pressure, and adverse effects.

\section{Statistical analysis}

Values were expressed as means \pm SD. The Wilcoxon signed-rank test was used to compare the values of clinical parameters. A p value $<0.05$ was considered to indicate a statistically significant difference.

\section{Results}

The baseline characteristics of the 13 patients are shown in Table 1. The mean $\mathrm{C} 2$ level of the initial CsA dose was $794 \pm 215$ (423-1,066) ng/mL (Table 2). The induction rate of remission was $100 \%$. Complete remission was achieved in 9 
Intern Med 50: 1905-1910, 2011 DOI: 10.2169/internalmedicine.50.5606

Table 1. Baseline Characteristics of 13 Nephrotic Patients with Idiopathic Membranous Nephropathy

\begin{tabular}{cc}
\hline Parameters & Values \\
\hline Age, years & $60 \pm 17$ \\
Men/Women & $8 / 5$ \\
Systolic blood pressure, $\mathrm{mmHg}$ & $134 \pm 14$ \\
Diastolic blood pressure, $\mathrm{mmHg}$ & $75 \pm 10$ \\
Urinary protein, g/d & $6.9 \pm 2.3$ \\
Serum albumin, g/dL & $2.2 \pm 0.5$ \\
Total cholesterol, mg/dL & $367 \pm 80$ \\
Serum creatinine, $\mathrm{mg} / \mathrm{dL}$ & $0.95 \pm 0.27$ \\
estimated GFR, mL/min/1.73 m² & $61.1 \pm 21.3$ \\
Global sclerosis, $\%$ & $19.0 \pm 19.1(0-50)$ \\
Tubulointerstitial changes (0-1-2-3) & $1-5-5-2$ \\
Vascular lesions (0-1-2-3) & $4-3-5-1$ \\
MGN stage (1-2-3-4) & $4-7-2-0$ \\
\hline
\end{tabular}

The severity of glomerular sclerosis was expressed as a percentage of totally sclerosed glomeruli, whereas that of tubulointerstitial changes or vascular lesions was assessed using the semiquantitative scoring $(0-4): 0=$ absent, $1=$ mild, $2=$ moderate, $3=$ severe.

Table 2. Changes in Daily Urinary Protein in Each Patient after Treatment

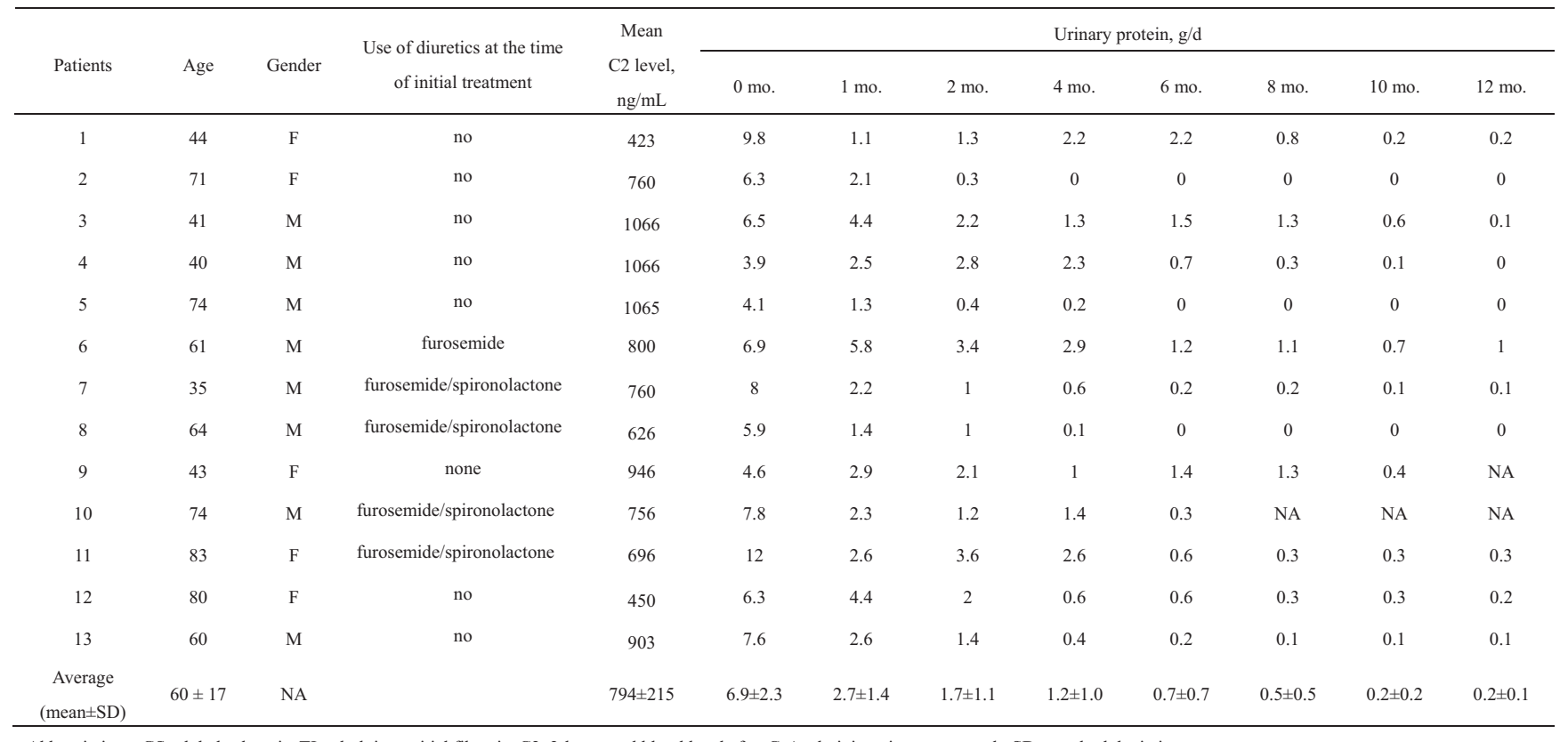

Abbreviations: GS, global sclerosis; TI, tubulointerstitial fibrosis; C2, 2-hour total blood level after CsA administration; mo, month; SD, standard deviation

patients, and incomplete remission $\mathrm{I}$ in 3 patients, and incomplete remission II in 1 patient (Table 2). The mean time to complete remission was $6.7 \pm 2.9$ months, with the earliest response at 2 months (patient 2) and the most delayed response at 12 months (patient 3) (Table 2). The serum albumin level increased from $2.2 \pm 0.5 \mathrm{~g} / \mathrm{dL}$ at baseline to $4.0 \pm 0.4$ $\mathrm{g} / \mathrm{dL}(\mathrm{P}<0.01)$ in remission. The 13 patients were followed up for a mean of $32.5 \pm 20.0$ months after the initiation of this treatment. The serum creatinine and eGFR values on final observation were identical to baseline levels (Table 3). Systolic blood pressure significantly decreased from $134 \pm 14$ $\mathrm{mmHg}$ to $124 \pm 12 \mathrm{mmHg}(\mathrm{P}<0.05)$ but diastolic blood pressure did not $(75 \pm 10$ and $74 \pm 10 \mathrm{mmHg})$ (Table 3$)$. In 3 pa- tients (patients 6, 12, and 13), serum creatinine levels increased to $>30 \%$ of the baseline level after the initial CsA dose; however, reducing the CsA dose by $25 \mathrm{mg}$ lowered the increasing serum creatinine levels to $<30 \%$ of the baseline level.

In one patient (patient 6), diabetes developed (HbA1c of $4.8 \%$ at baseline increased to a maximum of $8.4 \%$ at 6 months after the initiation of treatment) and the patient showed an elevated transaminase level. However, reducing the CsA dose by $25 \mathrm{mg}$ or a more rapid tapering of the PSL dose ameliorated the hyperglycemia (HbA1c of $5.1 \%$ at final observation) and resolved the liver damage. In the other 12 patients, the levels of fasting plasma glucose significantly 
Table 3. Clinical Parameters before and after Treatment

\begin{tabular}{|c|c|c|c|c|c|c|c|c|c|c|c|}
\hline Patients & $\begin{array}{l}\text { Observation, } \\
\text { mo }\end{array}$ & $\begin{array}{c}\text { Baseline BP, } \\
\text { mmHg }\end{array}$ & $\begin{array}{c}\text { Final BP, } \\
\text { mmHg }\end{array}$ & $\begin{array}{c}\text { Baseline } \\
\mathrm{Cr}, \mathrm{mg} / \mathrm{dL}\end{array}$ & $\begin{array}{c}\text { Final } \\
\mathrm{Cr}, \mathrm{mg} / \mathrm{dL}\end{array}$ & $\begin{array}{c}\text { Baseline } \\
\text { eGFR, } \\
\mathrm{mL} / \mathrm{min} 1.73 \\
\mathrm{~m}^{2}\end{array}$ & $\begin{array}{c}\text { Final } \\
\text { eGFR, } \\
\mathrm{mL} / \mathrm{min} / 1.73 \\
\mathrm{~m}^{2}\end{array}$ & $\begin{array}{l}\text { Final urinary } \\
\text { protein, } g / d\end{array}$ & $\begin{array}{c}\text { Duration } \\
\text { after } \\
\text { stopping } \\
\text { CsA, mo }\end{array}$ & Relapse & Final treatment, \\
\hline 1 & 22 & $112 / 56$ & $93 / 56$ & 0.54 & 0.67 & 90.8 & 74 & 0.1 & 4 & no & none \\
\hline 2 & 36 & $133 / 86$ & $125 / 77$ & 0.64 & 0.62 & 67.7 & 70.3 & 0.6 & 18 & no & VAL $80 \mathrm{mg}$ \\
\hline 3 & 45 & $125 / 68$ & $122 / 72$ & 0.88 & 0.93 & 70.7 & 66.4 & 1.4 & 11 & no & LOS $50 \mathrm{mg}$ \\
\hline 4 & 52 & $142 / 66$ & $136 / 86$ & 0.88 & 0.73 & 71.1 & 88.2 & 0 & 31 & no & none \\
\hline 5 & 50 & $124 / 78$ & $118 / 70$ & 0.59 & 0.68 & 99.5 & 84.2 & 0 & 30 & no & none \\
\hline 6 & 56 & $158 / 80$ & $134 / 82$ & 1.42 & 1.73 & 37.6 & 29.9 & 1.1 & 24 & no & OLM40mgLIS5mg/Furosemide20mg \\
\hline 7 & 66 & $146 / 82$ & $138 / 82$ & 1.01 & 0.94 & 62.3 & 67.6 & 0.9 & 42 & no & VAL160 mg/TEM2 mg/Cilinidipine $20 \mathrm{mg}$ \\
\hline 8 & 19 & $134 / 86$ & $137 / 89$ & 0.86 & 0.89 & 66.3 & 63.8 & 0 & 3 & no & CAN12 mg \\
\hline 9 & 10 & $143 / 84$ & $123 / 79$ & 1.35 & 0.96 & 34.8 & 50.6 & 0.4 & NA & $\mathrm{NA}^{\dagger}$ & $\begin{array}{l}\text { CsA100 mg/PSL10mg/LOS50 } \\
\mathrm{mg} / \text { hydrochlorothiazide } 12.5 \mathrm{mg}\end{array}$ \\
\hline 11 & 14 & $122 / 68$ & $120 / 65$ & 0.84 & 0.77 & 48.6 & 53.3 & 0.2 & NA & $\mathrm{NA}^{\neq}$ & CsA50mg/VAL40mg \\
\hline 12 & 34 & $118 / 64$ & $112 / 60$ & 1.20 & 1.20 & 32.0 & 32.0 & 0.3 & 14 & no & VAL160mg \\
\hline 13 & 14 & $147 / 80$ & $128 / 72$ & 1.03 & 1.02 & 58.3 & 58.6 & 0.1 & NA & $\mathrm{NA}^{*}$ & CsA50mg/PSL5mg/VAL80mg \\
\hline $\begin{array}{l}\text { Average, } \\
\text { mean } \pm \text { SD }\end{array}$ & $32.7 \pm 20.0$ & $\begin{array}{c}134 \pm 14 / \\
75 \pm 10\end{array}$ & $\begin{array}{c}124 \pm 12 / \\
74 \pm 10\end{array}$ & $0.95 \pm 0.27$ & $0.94 \pm 0.29$ & $61.1 \pm 21.3$ & $61.2 \pm 18.2$ & $0.4 \pm 0.5$ & $19.6 \pm 13.2$ & NA & NA \\
\hline
\end{tabular}

Abbreviations: BP, blood pressure; Cr, serum creatinine; eGFR, estimated glomerular filtration rate; CsA, cyclosporine; PSL, prednisolone; VAL, valsartan; LOS, losartan; OLM, olmesartan; CAN, candesartan; LIS, lisinopril; TEM, temocapril; NA, not available ${ }^{\dagger}$ The patient was given the initial dose of $\mathrm{CsA}$; ${ }^{\ddagger}$ The patient was given a tapered dose of $\mathrm{CsA}$ after 12 months of the initial treatment.

increased after treatment (from $88 \pm 5 \mathrm{mg} / \mathrm{dL}$ at baseline to $103 \pm 9 \mathrm{mg} / \mathrm{dL} 6$ months after the initial treatment, $\mathrm{P}<$ 0.0001 ), but significantly decreased to $91 \pm 9 \mathrm{mg} / \mathrm{dL}$ at final observation, eventually becoming equal to the baseline levels.

An 83-year-old woman (patient 11) previously experienced cytomegalovirus (CMV) enterocolitis, but had been successively treated with ganciclovir. There were no critical adverse effects which required discontinuation of therapy. On final observation, all patients were in remission (6 complete remission, 5 incomplete remission I, 2 incomplete remission II) (Table 3). Two patients continued to receive the initial CsA dose, and 2 patients continued to receive the tapered CsA dose 12 months after the initial treatment dose. The remaining 9 patients who completed treatment had not relapsed at 19.6 \pm 13.2 months after cessation of CsA (Table 3).

\section{Discussion}

We set out to assess the efficacy of single daily dose CsA combined with low-dose PSL and an ARB in patients with IMN. Conservative treatment for IMN is supported by occasional spontaneous remission. According to the most recent retrospective analysis of 328 nephrotic patients with IMN, only $16 \%$ developed complete remission by conservative follow-up at 38.5 \pm 25.2 months after diagnosis (9). Generally, attaining complete remission in patients with IMN is associated with good long-term outcomes (14). Therefore, more early effective immunosuppressive therapy might be considered. In this respect, the present study showed a higher remission rate than recent studies of CsA combined with low-dose PSL in nephrotic patients with IMN (15-19) (Table 4). This may be explained by several characteristics of our treatment protocol.

First, a single daily dose of CsA, which was used in the present study, may by itself yield good results (Table 4). A single daily dose of CsA is associated with a high peak level or low trough level compared with a twice-daily dose. In patients with renal transplants, high peak levels correlated with a low incidence of graft rejection (20), while nephrotoxic episodes appeared to correlate with high trough levels (21). Several studies have documented the effectiveness of a single daily dose of $\mathrm{CsA}$ in children $(7,22)$ or adults (12) with nephrotic syndrome. In addition, the singledose therapy in these studies was associated with lower total CsA daily doses or fewer side effects than the twice-daily dose therapy $(7,8)$. In a recent study in children with steroid-dependent nephrotic syndrome, 1- to 2-hour blood concentrations of $600-800 \mathrm{ng} / \mathrm{mL}$ were shown to be effective (22). For the concern regarding the co-administered low-dose PSL, a combination of CsA and PSL increases the chance of complete remission more than CsA monotherapy (17).

Second, the co-administration of an ARB may help achieve remission. Reports concerning simultaneous ARB administration with CsA in IMN are scarce (19). However, in the present study, the combination appeared to be effective for 2 reasons: CsA has immunosuppressive and hemodynamic effects different from those of an ARB; CsA constricts afferent arterioles selectively (23) while an ARB predominantly dilates efferent arterioles. Proteinuria in IMN is possibly associated with immune complex mediatedglomerular podocyte injuries, and increased glomerular pres- 
Table 4. Reports of Treatment with Low-dose CsA Combined with Low-dose PSL in Nephrotic Patients with IMN

\begin{tabular}{|c|c|c|c|c|c|c|c|c|c|c|c|c|c|}
\hline Authors, year & $\begin{array}{l}\text { Patients } \\
\text { (n) }\end{array}$ & $\begin{array}{l}\text { Previous } \\
\text { therapy }\end{array}$ & $\begin{array}{c}\text { Initial CsA } \\
\text { dose, } \\
\mathrm{mg} / \mathrm{kg} / \mathrm{d}\end{array}$ & $\begin{array}{c}\text { Daily } \\
\text { dose of } \\
\text { CsA }\end{array}$ & $\begin{array}{l}\text { Duration } \\
\text { of initial } \\
\text { CsA, mo }\end{array}$ & $\begin{array}{l}\text { Tapering of } \\
\text { CsA }\end{array}$ & $\begin{array}{c}\text { PSL } \\
\text { dose } \\
\mathrm{mg} / \mathrm{kg} / \mathrm{d}\end{array}$ & $\begin{array}{l}\mathrm{ARB} / \text { or } \\
\mathrm{ACE}-\mathrm{I}\end{array}$ & $\begin{array}{c}\mathrm{Cr} \\
\mathrm{mg} / \mathrm{dL}\end{array}$ & Up, g/d & $\begin{array}{l}\text { Follow } \\
\text { up, mo }\end{array}$ & $\begin{array}{c}\text { Remission } \\
\text { CR/PR }\end{array}$ & $\begin{array}{c}\text { Relapse of } \\
\text { NS }\end{array}$ \\
\hline $\begin{array}{l}\text { Iida H, } \\
2000\end{array}$ & 8 & yes & 3.0 & $\begin{array}{c}\text { Two } \\
\text { divided }\end{array}$ & $12-24$ & NA & $\begin{array}{c}20 \pm 9.7 \\
\mathrm{mg} / \mathrm{d}\end{array}$ & $2 / 8$ & $\begin{array}{c}1.1 \pm \\
0.4\end{array}$ & $8.4 \pm 4.1$ & 24 & $\begin{array}{r}7(88 \%) \\
3 \quad 4\end{array}$ & NA \\
\hline $\begin{array}{c}\text { Cattran DC, } \\
2001\end{array}$ & 28 & yes & 3.7 & $\begin{array}{c}\text { Two } \\
\text { divided }\end{array}$ & 6.5 & over 4 wks & 0.15 & No & $\begin{array}{c}1.3 \pm \\
0.5\end{array}$ & $\begin{array}{c}10.3 \pm \\
4.0\end{array}$ & 19.5 & $\begin{array}{cr}21 & (75 \%) \\
2 & 19\end{array}$ & $9 / 12$ \\
\hline $\begin{array}{l}\text { Alexopoulos E, } \\
2006\end{array}$ & 31 & no & $2-3$ & $\begin{array}{c}\text { Two } \\
\text { divided }\end{array}$ & 12 & $\begin{array}{l}\text { over a period } \\
\text { of } 2 \text { mo }\end{array}$ & 0.6 & allowed & $\begin{array}{c}1.2 \pm \\
0.4\end{array}$ & $5.1 \pm 2.5$ & $26 \pm 16$ & $\begin{array}{l}26(84 \%) \\
11 \quad 15\end{array}$ & $4 / 26$ \\
\hline $\begin{array}{c}\text { Goumenos DS, } \\
2007\end{array}$ & 46 & NA & $2-3$ & $\begin{array}{c}\text { Two } \\
\text { divided }\end{array}$ & 18 & $\begin{array}{l}0.5 \mathrm{mg} / \mathrm{kg} / \mathrm{mo} \\
\text { for } 6 \mathrm{mo}\end{array}$ & $\begin{array}{c}\mathrm{mPSL} \\
0.4\end{array}$ & $36 / 46$ & $\begin{array}{c}1.1 \pm \\
0.3\end{array}$ & $7.4 \pm 4.3$ & $48 \pm 36$ & $\begin{array}{l}39(85 \%) \\
29 \quad 10\end{array}$ & $16 / 39$ \\
\hline $\begin{array}{l}\text { Li J, } 2010 \text {, } \\
2010\end{array}$ & 18 & Yes in 12 & $1-1.5$ & $\begin{array}{c}\text { Two } \\
\text { divided }\end{array}$ & At least 6 & $\begin{array}{l}10 \text { to } 20 \% \\
\text { every mo }\end{array}$ & $0.15-0.5$ & $18 / 18$ & $\begin{array}{c}0.8 \pm \\
0.1\end{array}$ & $6.4 \pm 2.6$ & $11 \pm 4$ & $\begin{array}{c}11(61 \%) \\
6 \quad 5\end{array}$ & NA \\
\hline Present study & 13 & no & 2 & Single & 12 & $\begin{array}{c}25 \mathrm{mg} \text { every } \\
2 \mathrm{mo}\end{array}$ & 0.5 & $13 / 13$ & $\begin{array}{c}0.9 \pm \\
0.3\end{array}$ & $6.9 \pm 2.3$ & $33 \pm 20$ & $\begin{array}{c}13(100 \%) \\
9 \quad 4\end{array}$ & $0 / 9^{\S}$ \\
\hline
\end{tabular}

Abbreviations: previous therapy, previous prednisolone or immunosuppressive therapy; CsA, cyclosporine; PSL, prednisolone; mPSL, methylprednisolone; ARB, angiotensin II receptor blocker; ACE-I, angiotensin converting enzyme inhibitor; Cr, serum creatinine; Up, urinary protein; CR, complete remission; PR, partial remission; NS, nephrotic syndrome; IMN, idiopathic membranous nephropathy; NA, not available ${ }^{\S}$ The 9 patients who completed the treatment protocol have not relapsed at the time of writing.

sure results in further enhancement of proteinuria and nephron loss (24). Therefore, intensive combination therapy with CsA and an ARB might be beneficial, with a decrease in intraglomerular pressure. In addition, 2 previous reports have documented that losartan or enalapril prevents experimental CsA-induced interstitial fibrosis $(10,11)$.

Third, we should consider the possible effects of racial differences in treatment resposiveness $(25,26)$. A previous CsA pharmacokinetic study reported bioavailability to be significantly lower in Black patients than in Caucasian patients, although the mechanism underlying this racial difference remains unknown (25). In this regard, it is possible that Japanese patients have a slower metabolism or higher absorption of CsA than Caucasian patients. The Research Group on Progressive Renal Disease in Japan reported that steroid therapy appeared to be useful for Japanese patients, although it has not been recommended for IMN in most review articles (26).

Fourth, we studied non-treated patients with new-onset nephrotic syndrome. Therefore it is likely that some of the target patients might remit only with corticosteroid.

Relapse is common on CsA withdrawal (15). Since there is no clinical method to predict relapse, we scheduled regimens with long maintenance periods (12 months) for the initial CsA dose, and then performed slow tapering of the drug in an attempt to prevent relapse. During therapy, none of 9 patients relapsed after stopping CsA. Thus, an extended treatment period of CsA followed by slow tapering of the drug may be required in IMN. Considering the effect of low-dose PSL on relapse prevention, relapses occurred more frequently in the CsA monotherapy group than in the CsA and PSL combination group (17).

One major concern with the use of CsA has been its potential for inducing nephrotoxicity. Although 6 patients had a decreased eGFR of $<60 \mathrm{~mL} / \mathrm{min} / 1.73 \mathrm{~m}^{2}$ at baseline, only 1 patient showed moderately decreased renal function at final follow-up. Patient 6, who showed a $22 \%$ decrease in
eGFR and persistent proteinuria of $>1 \mathrm{~g} / \mathrm{d}$ at final observation, had a long history of hypertension, continuous heavy proteinuria over 6 months, and showed severe interstitial fibrosis with focal tubular atrophy and severe vascular lesions. Therefore, care must be taken when determining indications for the timing of giving this therapy to such patients.

Conversely, the eGFR of patient 9 increased after treatment. Hladunewich et al suggested that the onset of IMN is accompanied by a marked reduction in the hydraulic permeability of the glomerular wall (27). This is partially offset by enhancement of the filtration surface area and by marked reduction in glomerular oncotic pressure, resulting in a relatively stable GFR. It was possible that the hypofiltration noted in patient 9 at baseline was the consequence of inadequate compensation caused by conditions which could be improved by this treatment in the current study.

A limitation of the present study was the small number of patients without controls. However, we believe that the study is valuable because we report a new treatment combination of single daily dose CsA plus low-dose PSL plus $\mathrm{ARB}$, together with an unusual dosage method (single daily dose) of CsA in IMN, and with a prospective follow-up.

In conclusion, a single daily dose of CsA combined with a low dose of PSL and an ARB in new-onset nephrotic patients with IMN induced a high remission rate of nephrotic syndrome, with a low incidence of relapse and a low risk of adverse effects. The triple therapy and prospective follow-up shows potential as a treatment approach for patients with IMN.

\section{The authors state that they have no Conflict of Interest (COI).}

\section{Acknowledgement}

The authors are indebted to Mr. Roderick J. Turner, Assistant Professor Edward F. Barroga and Professor J. Patrick Barron of the Department of International Medical Communications of Tokyo Medical University for their review of the manuscript. 


\section{References}

1. Reichert U, Koene RA, Wetzels JF. Prognostic factors in idiopathic membranous nephropathy. Am J Kidney Dis 31: 1-11, 1998.

2. Hogan S, Muller KE, Jennette JC, Falk RJ. A review of therapeutic studies of idiopathic membranous nephropathy. Am J Kidney Dis 25: 862-875, 1995.

3. Ponticelli C, Zucchelli P, Passerini P, et al. A 10-year follow-up of a randomized study with methylprednisolone and chlorambucil in membranous nephropathy. Kidney Int 48: 1600-1604, 1995.

4. Ponticelli C, Altieri P, Scolari F, et al. A randomized study comparing methylprednisolone plus chlorambucil versus methylprednisolone plus cyclophosphamide in idiopathic membranous nephropathy. J Am Soc Nephrol 9: 444-450, 1998.

5. du Buf-Vereijken PW, Branten AJ, Wetzels JF. Cytotoxic therapy for membranous nephropathy and renal insufficiency: Improved renal survival but high relapse rate. Nephrol Dial Transplant 19: 1142-1148, 2004.

6. Cattran DC, Greenwood C, Ritchie S, et al. A controlled trial of cyclosporine in patients with progressive membranous nephropathy. Kidney Int 47: 1130-1135, 1995.

7. Chishti AS, Sorof JM, Brewer ED, Kale AS. Long-term treatment of focal segmental glomerulosclerosis in children with cyclosporine given as a single daily dose. Am J Kidney Dis 38: 754760, 2001.

8. Schadeli F, Marti HP, Frey FJ, Uehlinger DE. Population pharmacokinetic model to predict steady-state exposure to once-daily cyclosporine microemulsion in renal transplant recipients. Clin Pharmacokinet 41: 59-69, 2002.

9. Polanco N, Gutierrez E, Covarsi A, et al. Spontaneous remission of nephrotic syndrome in idiopathic membranous nephropathy. J Am Soc Nephrol 21: 697-704, 2010.

10. Burdmann EA, Ando TF, Nast CC, et al. Prevention of experimental cyclosporine-induced interstitial fibrosis by losartan and enalapril. Am J Physiol 269: F491-F498, 1995.

11. Shihab FS, Bennett WM, Tanner AM, Andoh TF. Angiotensin II blockade decreases TGF- $\beta 1$ and matrix proteins in cyclosporine nephropathy. Kidney Int 52: 660-673, 1997.

12. Rasche FM, Keller F, Kunze G, Boesler B, Czock D. Single daily dose cyclosporine in patients with primary glomerulonephritis and nephrotic syndrome. Clin Nephrol 67: 285-292, 2007.

13. Matsuo S, Imai E, Horio M, et al. Revised equations for estimated GFR from serum creatinine in Japan. Am J Kidney Dis 53: 982992, 2009.

14. Laluck BJ Jr, Cattran DC. Prognosis after a complete remission in adult patients with idiopathic membranous nephropathy. Am J
Kidney Dis 33: 1026-1032, 1999.

15. Cattran DC, Appel GB, Hebert LA, et al. Cyclosporine in patients with steroid-resistant membranous nephropathy: A randomized trial. Kidney Int 59: 1484-1490, 2001.

16. Iida H, Naito T, Sakai N, Aoki S. Effect of cyclosporine therapy on idiopathic membranous nephropathy presented with refractory nephrotic syndrome. Clin Exp Nephrol 4: 81-85, 2000.

17. Alexopoulos E, Papagianni A, Tsamelashvili M, Leontsini M, Memmos D. Induction and long-term treatment with cyclosporine in membranous nephropathy with the nephrotic syndrome. Nephrol Dial Transplant 21: 3127-3132, 2006.

18. Goumenos DS, Katopodis KP, Passadakis P, et al. Corticosteroids and cyclosporin A in idiopathic membranous nephropathy: Higher remission rates of nephrotic syndrome and less adverse reactions than after traditional treatment with cytotoxic drugs. Am J Nephrol 27: 226-231, 2007.

19. Li J, Zhang YM, Qu Z, Zhao MH, Liu G. Low-dose cyclosporine treatment in Chinese nephrotic patients with idiopathic membranous nephropathy: An uncontrolled study with prospective followup. Am J Med Sci 339: 532-536, 2010.

20. Mahalati K, Lawen J, Kiberd B, Belitsky P. Is 3-hour cyclosporine blood level in early post-renal transplantation period? J Urol 163: $37-41,2000$.

21. Mahalati K, Belitsky P, Sketris I, West K, Panek R. Neoral monitoring by simplified sparse sampling area under the concentrationtime curve: its relationship to acute rejection and cyclosporine nephrotoxicity early after kidney transplantation. Transplantation 68: 55-62, 1999.

22. Nakahata $T$, Tanaka $H$, Tsugawa $K$, et al. $C_{1}-C_{2}$ point monitoring of low-dose cyclosporine a given as a single daily dose in children with steroid-dependent relapsing nephrotic syndrome. Clin Nephrol 64: 258-263, 2005.

23. Ambalavanan S, Fauvel JP, Sibley RK, Myers BD. Mechanism of the antiproteinuric effect of cyclosporine in membranous nephropathy. J Am Soc Neprol 7: 290-298, 1996.

24. Pavenstadt H, Kriz W, Kretzler M. Cell biology of the glomerular podocyte. Physiol Rev 83: 253-307, 2003.

25. Linholm A, Welsh M, Alton C, Kahan BD. Demographic factors influencing cyclosporine pharmacokinetic parameters in patients uremia: Racial differences in bioavailability. Clin Pharmacol Ther 52: 359-371, 1992.

26. Shiiki H, Saito T, Nishitani Y, et al. Prognosis and risk factors for idiopathic membranous nephropathy with nephrotic syndrome. Kidney Int 65: 1400-1407, 2004.

27. Hladunewich MA, Lemley KV, Blouch KL, Myers BD. Determinations of GFR depression in early membranous nephropathy. Am J Physiol Renal Physiol 284: F1014-F1022, 2003.

\footnotetext{
(C) 2011 The Japanese Society of Internal Medicine http://www.naika.or.jp/imindex.html
} 